\title{
US administration's parsimony criticized
}

\section{Washington}

THE Reagan administration has consistently refused to seek adequate support for research into acquired immune deficiency syndrome (AIDS), according to a study by the Congress's Office of Technology Assessment (OTA) released last week.

While praising the government scientists who have carried out much of the research. so far on AIDS, the OTA study chastised the Department of Health and Human Services for repeatedly rebuffing the recom- such test, but has not announced a firm date. In the meantime, criticism of the impending implementation of the tests, which detect antibody to the AIDS virus, is threatening to boil over. A number of bloodbank officials and clinical physicians worry about being placed in the impossible position of having to explain to patients the unknown significance of a positive test result. And homosexual organizations worry that test results, especially if they became part of a patient's permanent medical records,

$\begin{array}{cccc} & \begin{array}{c}\text { Internal } \\ \text { PHS request }\end{array} & \begin{array}{c}\text { Official administration } \\ \text { request }\end{array} & \begin{array}{c}\text { Congressional } \\ \text { appropriation }\end{array} \\ 1986 & \text { not available } & \$ 86 \text { million } & \text { not available } \\ 1985 & \$ 91 \text { million } & \$ 61 \text { million } & \$ 97 \text { million } \\ 1984 & \$ 60 \text { million } & \$ 40 \text { million } & \$ 61 \text { million } \\ 1983 & \text { not available } & - & \$ 29 \text { million } \\ 1982 & - & - & \$ 6 \text { million }\end{array}$

Source: Review of the Public Health Services's response to AIDS, Office of Technology Assessment Technical Memorandum OTA-TM-H-24, February 1985.

mendations of its own Public Health Service (PHS) agencies for emergency increases in AIDS research funds. For the past three years, Congress has provided additional support in spite of objections from the administration (see table). The administration is proposing to hold the AIDS research budget for next year at the current level of $\$ 86$ million.

The official administration line continues to be that the Public Health Service can handle the AIDS crisis by shifting funds and personnel from other areas. The Centers for Disease Control (CDC) have cut back work on hepatitis B and sexuallytransmitted diseases in order to supplement research on AIDS, the Food and Drug Administration has cut back work on hepatitis vaccine and the National Institutes of Health (NIH) have shifted resources mainly from cancer research.

The OTA study points to several indicators that support remains inadequate, despite congressional action (based on leaked documents showing the original budget plans submitted by the PHS agencies) to appropriate additional monies: the study notes continued rivalries between PHS agencies, notably NIH and CDC, for funding; recommendations by two National Cancer Institute advisory committees that support must be increased; and the privately voiced opinions of "numerous" federal and non-federal scientists that current efforts are inadequate.

The study also criticized the fanfare surrounding Secretary of Health and Human Services Margaret Heckler's announcement last April that the causative agent of AIDS had been isolated and that a blood test would be on the market within six months. FDA says it will shortly license the first could be used as grounds for denying life or health insurance or employment; furthermore, given the high level of exposure to the virus among male homosexuals, the fear is that employers could use the test simply as an indicator of homosexuality.

The National Gay Task Force has recommended that the test be used only for screening the blood supply and for clinical research; it has urged its members not to take the test. Another homosexual rights organization, the Lambda Legal Defense Fund, is threatening to take FDA to court to halt licensing of the test until "adequate safeguards" are adopted to prevent misuse.

FDA last week took some hasty action to allay concern by calling a meeting at which the five manufacturers developing the tests "voluntarily" waived their proprietary rights to confidentiality and announced the results of clinical trials to their products. Abbott Laboratories, which is considered to have an edge over its competitors - certainly in production capacity - announced that its test accurately detected 95 per cent of a group of 119 diagnosed AIDS patients; when tested on 17,000 random blood donors, 99.8 per cent came up negative. That rate is within the range that might plausibly be expected for the general public.

FDA also announced that it is sending out a letter to 500,000 physicians in the United States warning that the test's primary purpose is screening the blood supply and that it is not a test for AIDS but only for antibody to AIDS, which may mean any number of things; that the patient will develop AIDS in a few years, that he is asymptomatically carrying the virus but will never become ill; and that the test has significant limitations when applied outside a research setting to asymptomatic persons - where the false-positive problem most noticeably manifests itself.

Once the test is licensed, however, FDA is powerless to limit its use by physicians. Meanwhile, the statistics on AIDS incidence continue to mount. CDC now list 8,500 reported cases of AIDS; given the delays in reporting, CDC estimate that as many as 1,700 additional cases may already have been diagnosed and will be reported within the next three months. The number of cases is expected to double by the end of the year.

\section{Animal welfare}

\section{Protesters as laboratory animals}

ANIMAL rights groups in Britain seem to be making modest headway. Last week, Bromley magistrates' court fined the Royal College of Surgeons $£ 250$ for causing unnecessary suffering to a macaque monkey at the college's Buckston Browne Research Establishment. This test case was brought by the British Union for the Abolition of Vivisection as the direct result of a raid on the research farm last summer. The monkey in question was severely dehydrated because of inadequate ventilation and high temperatures $\left(85-92^{\circ} \mathrm{F}\right)$. The college plans to appeal.

Meanwhile, members of the Middlesex animal rights group have thrown down a challenge for researchers by offering themselves as subjects in anti-viral antibody testing, usually done with rabbits. The offer was made after the group was invited to tour the Colindale Public Health Laboratory last year, when the laboratory was opened to the public in an attempt to defuse local panic about work related to
Lassa fever. The laboratory has refused to perform the antibody testing experiments on human subjects because they would be unethical, unsafe, impractical and of limited scientific use.

Mr Peter Georghiades, representing the animal rights group, wants to discuss the offer further with the laboratory and to investigate other projects that could involve human volunteers. In the face of Colindale's refusal, the group plans to inform the Minister of Health of the offer.

Animal rights groups are unconvinced about government legislation on animal experiments. A Home Office white paper (policy document), supplementary to that produced in 1983 (see Nature, 303, 191; 1983), will be published "before Easter". It will propose stricter guidelines on the infliction of pain and suffering, but in $\mathrm{Mr}$ Georghiades' view, will not go far enough. Non-scientists should have more control over the experiments that scientists may perform, he believes.
Maxine Clarke 